\title{
PGV-0 AND PGV-1 INCREASED APOPTOSIS INDUCTION OF DOXORUBICIN ON MCF-7 BREAST CANCER CELLS
}

\author{
Adam Hermawan ${ }^{1}$, Aditya Fitriasari ${ }^{1}$, Sendy Junedi ${ }^{1}$, Muthi Ikawati ${ }^{1}$, \\ Sari Haryanti ${ }^{1}$, Barinta Widaryanti ${ }^{1}, \mathbf{M ~ D a}^{\prime} \mathbf{i}^{1,2}$ and Edy Meiyanto ${ }^{1,3^{*}}$ \\ ${ }^{1}$ Faculty of Pharmacy Universitas Gadjah Mada Yogyakarta \\ ${ }^{2}$ Faculty of Pharmacy Universitas Muhammadiyah Surakarta \\ ${ }^{3}$ Cancer Chemoprevention Research Center \\ meiyan_e@ugm.ac.id
}

\begin{abstract}
As chemotherapeutic backbone for breast cancer therapy, doxorubicin showed various side effects and induced resistancy of breast cancer cells. Development of targeted therapy on breast cancer focused on combinatorial therapy of doxorubicin and molecular targeted agents. PGV-O and $P G V-1$, a curcumin analogue showed potency as co-chemotherapeutic agent with doxorubicin. Our previous study of PGV-0 and PGV-1 showed cytotoxic activity in T47D cells. Therefore, the aim of this research is to examine the synergistic effect of PGV-0, PGV-1 on the cytotoxic activity of doxorubicin through cell cycle modulation and apoptotic induction on MCF-7 breast cancer cell lines. The cytotoxic assay of PGV-0, PGV-1, doxorubicin, and their combination were carried out by using MTT assay. Cell cycle distribution and apoptosis were determined by flowcytometer FACSCalibur and the flowcytometry data was analyzed using Cell Quest program. Single treatment of $P G V-0, P G V-1$ and doxorubicin showed cytotoxic effect on MCF-7 with cell viability IC50 value 50 $\mu M, 6 \mu M$ and $350 \mathrm{nM}$ respectively. Single treatment of Doxorubicin $175 \mathrm{nM}$ induced G2/M arrest. Single treatment of PGV-0 $5 \mu M$ induced G2/M arrest while in higher dose $12.5 \mu M, P G V-0$ induced apoptosis. Combination of doxorubicin $175 \mathrm{nM}$ and PGV-0 $5 \mu \mathrm{M}$ induced apoptosis. Combination of doxorubicin $175 \mathrm{nM}$ and PGV-0 $12.5 \mu \mathrm{M}$ also increased apoptosis induction. Single treatment of PGV-1 $0.6 \mu \mathrm{M}$ induced G1 arrest while in higher dose $1.5 \mu \mathrm{M}$, PGV-1 induced apoptosis. Combination of doxorubicin $175 \mathrm{nM}$ and PGV-1 $0.6 \mu \mathrm{M}$ induced apoptosis. Combination of doxorubicin $175 \mathrm{nM}$ and PGV-0 $1.5 \mu \mathrm{M}$ also increased apoptosis induction. PGV-O and PGV-1 are potential to be delevoped as co-chemotherapeutic agent for breast cancer by inducing apoptosis and cell cycle modulation, but the molecular mechanism need to be explored detail.
\end{abstract}

Key words: PGV-0, PGV-1, doxorubicin, co-chemotherapy, breast cancer, cell cycle arrest, apoptosis

\section{INTRODUCTION}

Breast cancer is one of most the deathcause cancer in women in the world (Jemal et al., 2007). Doxorubicin is one of chemotherapeutic agent mostly used in breast cancer therapy. Using of doxorubicin at high dose causes side effect on normal tissue, primarily on heart, and suppression of immune system. Breast cancer cells also showed resistance to chemotherapeutic agent such as doxorubicin. To improve the antitumor efficacy of chemotherapy, a combination with chemopreventive agent (co-chemotherapy) would be interesting to evaluate.

PGV-0 [Pentagamavunon-0 (2,5-bis-(4'hydroxy-3'-methoxybenzilidine)-

cyclopentanone)] and PGV-1 [Pentagamavunon-1 (2,5-bis-(4'-hydroxi, 3', 5' $^{\prime}$-dimethyl)benzylidin-cylopentanone)], a curcumin analogue, shows stronger cytotoxic effect than curcumin in several cancer cell lines. Our previous study of PGV-0 cytotoxic activity on T47D cells with IC50 of $9.4 \mu \mathrm{M}$ seemingly potential to be developed as combinatorial agent with doxorubicin. PGV-1 also showed cytotoxic activity on T47D cells with IC50 1.8 $\mu \mathrm{M}$ and represent a new microtubule inhibitor.

Those researches showed the potency of PGV-0 and PGV-1 as chemopreventive agent and became a basic for the development of $\mathrm{PGV}-0$ and PGV-1 as co-chemotherapeutic agent to increase the cytotoxic activity and reduce the side effects of doxorubicin. Therefore, the purpose of this research is to examine the effect of PGV-0 and PGV-1 and their combination with doxorubicin on cell cycle and apoptosis of MCF-7 breast cancer cells.

\section{METHODE \\ Cytotoxic Assay (MTT Method)}

The method was modified from Mosmann (1983). MCF-7 cells were cultured in Dulbecco's Modified Eagle's Medium (DMEM) containing Fetal Bovine Serum (FBS) 10\% (v/v) and penicillin-streptomycin $1 \%(\mathrm{v} / \mathrm{v})$. Cells $\left(5 \times 10^{3}\right.$ cells/well) were transfered to $96-$ well plate and incubated for 24 hours $(70-80 \%$ confluent). Cells were treated by PGV-0 (Curcumin Research Center UGM), PGV-1 (Curcumin Research Center UGM) doxorubicin (Ebewe), and their combination, and incubated for 24 hour. At the end of the incubation, MTT [3-(4,5-dimethylthiazol-2-yl)-2,5-diphenyl

tetrazolium bromide] $0,5 \mathrm{mg} / \mathrm{ml}$ were added to each wells and the cells were incubated for 4 hours in $37^{\circ} \mathrm{C}$. Viable cells reacts with MTT to form purple formazan crystal. After 4 hours, stopper sodium dodesil sulphate $10 \%$ in $0,1 \mathrm{~N}$ $\mathrm{HCl}$ solution were added to dissolve formazan crystal. Cells were incubated over night and protected from light. Cells were shaken for 10 minutes before read by ELISA reader at $\lambda 595$ 
nm. The absorbance of each well converted to percentage of viable cells :

$\%$ Viable cells =

Treated cells abs - Medium control abs $\times 100 \%$

Cells control abs - Medium control abs

\section{Flowcytometry Assay}

Cells $\left(5 \times 10^{5}\right.$ cells/well) were transferred into 6-well plate and incubated until the cells return to normal condition. Cells were treated by PGV-0, PGV-1, doxorubicin, and their combination, and incubated for 24 hours. At the end of the incubation, the media containing free cells suspension were taken and transferred into $1.5 \mathrm{ml}$ eppendorfs, then it were centrifugated (2000 rpm, 3 minutes) and the supernatant were removed. The cell in 6-well plate were added by PBS, and the PBS were transferred into previous eppendorfs. The eppendorfs were centrifugated and the supernatant were removed again. This steps were repeated before the cells harvested by trypsin-EDTA $0,025 \%$. Harvested cells were transferred into the eppendorfs and centrifugated (2000 rpm, 30 seconds). The remaining cells in the 6-well plate were rinsed with PBS and transferred into the eppendorfs. The eppendorfs were centrifugated and the supernatant were removed. Pellet cells in eppendorfs washed by cold PBS and added by propidium iodide $(\mathrm{PI})$ reagents. The eppendorfs were wrapped in aluminum foil and incubated in $37^{\circ} \mathrm{C}$ for 10 minutes. After 10 minutes, cell suspension were homogenated and transferred into the flowcyto-tube to be analyzed by flowcytometer.

\section{Result and Discussion}

PGV-0 and PGV-1 have been proved to have cytotoxic and antiproliferative effect against several cancer cell lines such as T47D, HeLa, Raji and Myeloma. In this research, single treatment of PGV-0 and PGV-1 showed cytotoxic effect on MCF-7 cells with $\mathrm{IC}_{50} 50 \mu \mathrm{M}$ and $6 \mu \mathrm{M}$ (Figure $1 \mathrm{~A}$ and Figure $1 \mathrm{~B}$ ). This result showed that the PGV-0 and PGV-1 potential as anticancer agent.

While doxorubicin showed strong cytotoxic effect in MCF-7 breast cancer cell lines (Figure 1C) with $\mathrm{IC}_{50} 350 \mathrm{nM}$. This is due to the characteristic of MCF-7 which is resistant to doxorubicin by overexpressing anti-apoptotic protein Bcl-2 and P-glycoprotein efflux pump (Davis et al., 2003). To increase the sensitivity of MCF-7 cells towards doxorubicin, we combined doxorubicin with PGV-0 and PGV-1

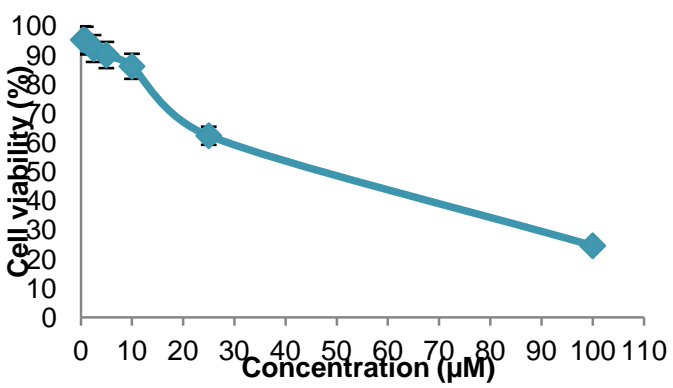

A

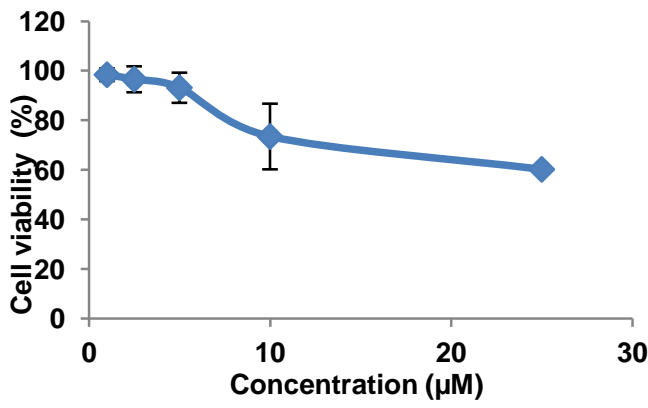

B

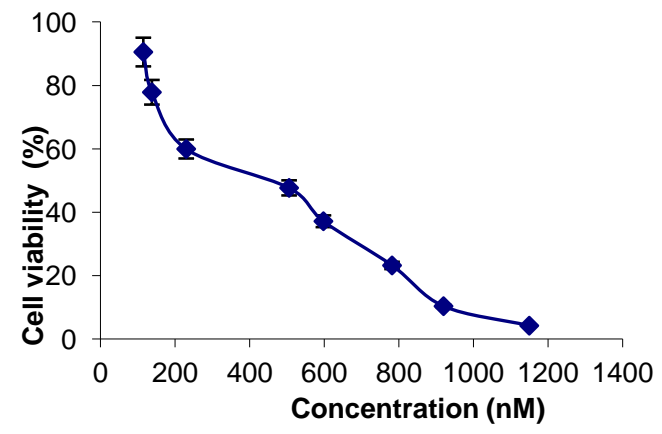

C

Figure 1-The effect of PGV-0 (A), PGV-1 (B) and doxorubicin (C) to the viability of MCF-7 breast cancer cells. The assay

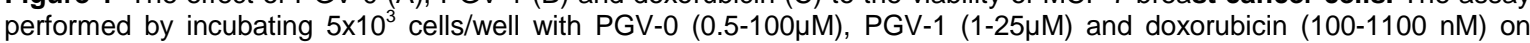
MCF-7 for 24 hours. After 24 hours, cells were added by MTT reagent to calculate the absorbance which represent viable cells. $I C_{50}$ value were calculated from linier regresion of log concentration vs $\%$ viable cell $(p<0,05)$. 
Synergistic effect of combination between PGV-0, PGV-1 and doxorubicin could be occured via cell cycle modulation (Table 1 and Figure 2). Cell cycle analysis of both breast cancer cell lines showed that single treatment of Doxorubicin $175 \mathrm{nM}$ induced G2/M arrest. Single treatment of PGV-0 $5 \mu \mathrm{M}$ induced G1 arrest, while in higher dose (12.5 $\mu \mathrm{M})$ PGV-0 induced apoptosis. Combination of doxorubicin 175 nM-PGV-0 $5 \mu \mathrm{M}$ induced apoptosis.
Combination of doxorubicin 175 nM-PGV-0 $12.5 \mu \mathrm{M}$ also increased apoptosis induction compared with control and doxorubicin single treatment. These results showed that the combination increased apoptosis induction of doxorubicin single treatment with dose dependent mechanism. The higher dose of PGV-O in combination, the higher of apoptosis induction occured.

Table 1-MCF-7 Cell distribution after treatment of PGV-0, PGV-1, doxorubicin, and their combination for 24 hours

\begin{tabular}{cccccc}
\hline Treatment & Concentration & $\begin{array}{c}\text { Sub G1 } \\
(\%)\end{array}$ & $\begin{array}{c}\text { G1 } \\
(\%)\end{array}$ & $\begin{array}{c}\text { S } \\
(\%)\end{array}$ & $\begin{array}{c}\text { G2/M } \\
(\%)\end{array}$ \\
\hline Control & - & 4.00 & 50.22 & 17.43 & 19.73 \\
Dox & $175 \mathrm{nM}$ & 8.21 & 26.08 & 9.00 & 52.03 \\
PGV-0 & $5 \mu \mathrm{M}$ & 8.72 & 65.25 & 8.96 & 12.01 \\
PGV-0 & $12.5 \mu \mathrm{M}$ & 19.74 & 27.39 & 19.50 & 27.28 \\
PGV-0+Dox & $5 \mu \mathrm{M}-175 \mathrm{nM}$ & 25.01 & 21.87 & 6.59 & 37.52 \\
PGV-0+Dox & $12.5 \mu \mathrm{M}-175 \mathrm{nM}$ & 44.33 & 34.15 & 6.67 & 11.57 \\
PGV-1 & $0.6 \mu \mathrm{M}$ & 3.77 & 60.11 & 11.20 & 16.80 \\
PGV-1 & $1.5 \mu \mathrm{M}$ & 24.58 & 18.68 & 12.09 & 25.92 \\
PGV-1+Dox & $0.6 \mu \mathrm{M}-175 \mathrm{nM}$ & 12.62 & 18.34 & 5.04 & 53.14 \\
PGV-1+Dox & $1.5 \mu \mathrm{M}-175 \mathrm{nM}$ & 34.13 & 27.92 & 6.89 & 29.07 \\
\hline
\end{tabular}

Single treatment of PGV-1 $0.6 \mu \mathrm{M}$ induced $\mathrm{G} 1$ arrest while in higher dose (1.5 $\mu \mathrm{M})$ PGV-1 induced apoptosis. Combination of doxorubicin $175 \mathrm{nM}-\mathrm{PGV}-1 \quad 0.6 \mu \mathrm{M}$ induced apoptosis. Combination of doxorubicin $175 \mathrm{nM}$ and PGV-0 $1.5 \mu \mathrm{M}$ also increased apoptosis induction than combination in lower dose of PGV-1. Single treatment both of PGV-0 and PGV-1 in lower dose induced G1 arrest, but in the higher dose both of them induced apoptosis. These results showed that the combination increased apoptosis induction of doxorubicin single treatment with dose dependent mechanism. The higher dose of PGV-1 in combination, the higher of apoptosis induction occured.

MCF-7 cells showed overexpression of Bcl-2 and P-glyco Protein (PgP) so that it is resistance to apoptosis. Single treatment of doxorubicin induced overexpression of $\mathrm{PgP}$ in MCF-7 cells (Mealey et al., 2002). Transport of drug using $\mathrm{PgP}$ need ATP to bring the drug outsid the cells (Chung et al., 2005), so that concentration of chemotherapeutic agent inside of cell will decrease and also decrease the efficacy of chemotherapeutics. Resistance of chemotherapeutics in cancer cells also caused by cell cycle arrest, so combination of chemotherapeutics with an agent which is induce apoptosis directly without cell cycle arrest mechanism is better than an agent which only acts in cell cycle arrest.

Single treatment of PGV-0 and PGV-1 in lower dose showed G1 arrest. Curcumin induced apoptosis via ROS generation (Moussavi et al., 2005) so that PGV-0 and PGV-1 probably induced apoptosis in the same pathway. In the lower dose, curcumin and its analogue probably does not enough to induce apoptosis and induce G1 arrest, but in the higher dose curcumin and its analogue induce apoptosis. In the high dose, curcumin upregulate p53 expression (Choudhuri et al., 2005) so that the apoptosis induction will be occured
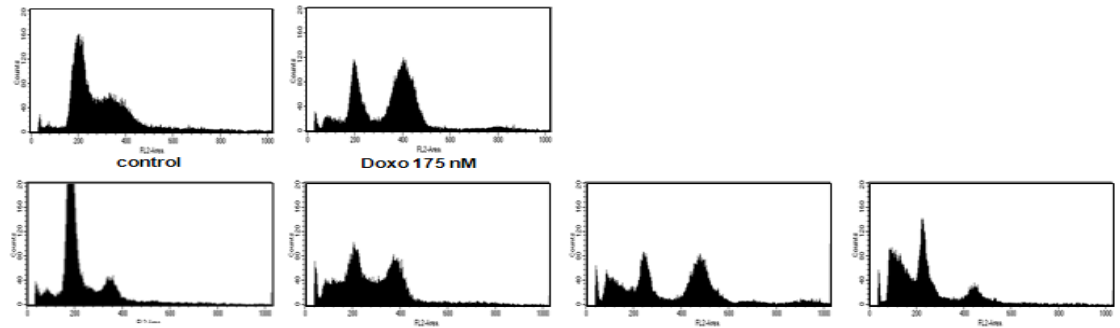

PGV-0 $12.5 \mu \mathrm{M}$

PGV ${ }^{2} 175 \mathrm{~nm}$ 12,5 PGV $0175 \mathrm{nM}$
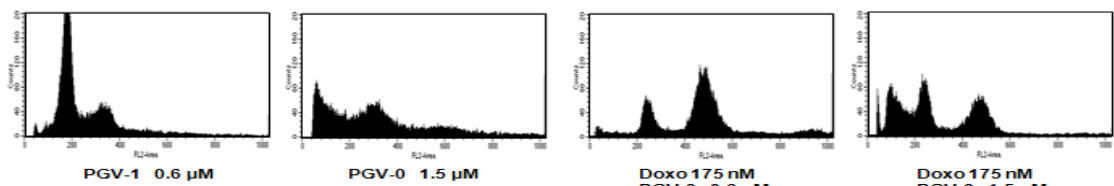

Figure 2-MCF-7 cell cycle analysis after treatment of PGV-0, PGV-1, doxorubicin, and their combination. MCF-7 cell were treated by PGV-0, doxorubicin, and their combination for 24 hours and stained by PI reagent before analyzed by flowcytometer. 
Apoptosis could be occured through mitochondrial independent pathway via Fas receptor by activating caspase 8 , or mitochondrial dependent pathway via activation p53 to transcript pro apoptotic regulator protein (Bad, Bax and Bid). MCF-7 cells expressed p53 so that apoptosis pathway occured via p53 pathway. Doxorubicin induces apoptosis through intrinsic mechanism via p53 pathway which is induce transcription of pro-apoptosis protein (Bax) (Minotti et al., 2004). Single treatment of doxorubicin $200 \mathrm{nM}$ in MCF-7 cells induced expression of $\mathrm{Bax}$ ( $\mathrm{Li}$ et al., 2007). Curcumin upregulate Bax in MCF-7/TH cells (Ramachandrand and You, 1999). PGV-0 and PGV-1 probably upregulate Bax and increased apoptosis induction, but it is need to be explore details.

Resistance of cancer cells is regulated by NF-kB (Olivier et al., 2006). Doxorubicin induced overexpression of $\mathrm{PgP}$ via activation of NF-KB (Wang et al., 2002). Doxorubicin also increase expression of phosporilated Akt kinase in MCF-7 cells (Li et al., 2005) which is also take a place in activation of NF-kB (Simstein et al., 2003). Activation of NF-kB will increase expression of $\mathrm{Bcl}-2$ so that cancer cells also resistant to apoptosis (Ruddon, 2007). Curcumin inhibited activation of NF-KB, downregulated $\mathrm{Bcl}-2$ and downregulated $\mathrm{Akt}$ (Agarwal and Shishoida, 2006). Inhibition of
$\mathrm{NF}-\mathrm{kB}$ activation will down regulated $\mathrm{PgP}$ and $\mathrm{Bcl}-2$, so that apoptosis will occured. Combination of PGV-0 and PGV-1 with doxorubicin probably inhibit activation of NF-KB, down regulated $\mathrm{PgP}$ and $\mathrm{Bcl}-2$, but the mechanism of combination need to be explored further.

This result showed the potency of PGV-0 and PGV-1 to be delevoped as co-chemotherapeutic agent for doxorubicin by inducing apoptosis and cell cycle arrest. The use of doxorubicin together with PGV-0 and PGV-1 is expected to increase the activity and reduce the side effects of doxorubicin. However, the molecular mechanism of apoptotic induction and cell cycle arrest by this combination need to be explored further.

\section{CONCLUSSION}

This research shows that combination of PGV-0, PGV-1 and doxorubicin synergically increase the effect of doxorubicin through apoptotic induction and cell cycle arrest. Based on this result, PGV-0 and PGV-1 are potential to be delevoped as co-chemotherapeutic agent for doxorubicin.

\section{ACKNOWLEDGEMENT}

Curcumin Research Center Faculty of Pharmacy UGM for supplying PGV-0 and PGV-1.

\section{REFERENCE}

Aggarwal, B., and Shishoida, S., 2006, Molecular Targets of Dietary Agents for Prevention and Therapy of Cancer, Biochemical Pharmacology, 71:1397-1421

Choudhuri, T., Pal, S., Das, T., and Sa, G., 2005, Apoptosis in Deregulated Cyclin D1-Expressed Cells at G2 Phase of Cell Cycle in a p53-dependent Manner, The Journal of Biological Chemistry, 280:20059-20068

Chung, S.Y., Sung, M.K., Kim, N.H., Jang, J.O., Go, E.J., and Lee, H.J., 2005, Inhibition of Pglycoprotein By Natural Products in Human Breast Cancer Cells, Arch Pharm Res., 28:823-828

Davis, J.M., Navolanic, P.M., Weinstein-Oppenheimer, C.R., Steelman, L.S., Wei H., Konopleva, M., Blagosklonny, M.V., and McCubrey, J.A., 2003, Raf-1 and Bcl-2 Induce Distinct and Common Pathways That Contribute to Breast Cancer Drug Resistance, Clinical Cancer Research, 9:11611170

Davis, J.M., Navolanic, P.M., Weinstein-Oppenheimer, C.R., Steelman, L.S., Wei H., Konopleva, M., Blagosklonny, M.V. and McCubrey, J.A. 2003. Raf-1 and Bcl-2 Induce Distinct and Common Pathways That Contribute to Breast Cancer Drug Resistance. Clin. Canc. Res. 9: 1161-1170

Jemal, A., Siegel, R., Ward, E., Murray, T., Jiaquan Xu and Michael J.T. 2007. Cancer Statistic 2007, CA Cancer J Clin., 57: 43-66

Kumar, R., Vadlamudi, R.K., and Adam, L., 2000, Apoptosis in Mammary Gland and Cancer, Endocr. Relat. Cancer, 7:257-269 
Li, S., Zhou, Y., Wang, R., Zhang, H., Dong Y., and Ip, C., 2007, Selenium Sensitizes MCF-7 Breast Cancer Cells to Doxorubicin-Induced Apoptosis Through Modulation of Phospho-Akt and Its Downstream Substrates, Mol Cancer Ther., 6:1031-1038

Li, X., Lu, Y.,Liang, K., Liu,B., dan Fan, Z., 2005, Differential responses to doxorubicin-induced phosphorylation and activation of Akt in human breast cancer cells, Breast Cancer Research, 7:589-597

Mealey, K.L., Barhoumi, R., Burghardt, R.C., Safe, S. and Kochevar, D.T. 2002. Doxycycline Induces Expression of P Glycoprotein in MCF-7 Breast Carcinoma Cells. Antimicrobial Agents and Chemotherapy 46(3): 755-761

Minotti, G., Menna, P., Salvatorelli, E., Cairo, G., and Gianni, L., 2004, Anthracyclins: Molecular Advances and Pharmacologic Developments in Antitumor Activity and Cardiotoxicity, Pharmacol. Rev., 56:185-228

Mosmann, T. 1983. Rapid Colorimetric Assay for Cellular Growth and Survival: Aplication to Proliferation and Citotoxicity Assays. J. Immunol Methods 65(1-2):55-63

Moussavi, M., Assi, K., Gomez-Munoz, A., and Baljinder, S., 2006, Curcumin Mediates Ceramide Generation Via The De Novo Pathway In Colon Cancer Cells, Carcinogenesis, in press

Olivier, S., Robe, P., and Bours, V., 2006, Can NF-kB be a Target for Novel and Efficient AntiCancer Agents?, Biochemical Pharmacology, 72:1054-1068

Ramachandran, C., and You, W., 1999, Differential Sensitivity of Human Mammary Epithelial and Breast Carcinoma Cell Lines to Curcumin, Breast Cancer Research and Treatment,54:269-278.

Ruddon, R.W., 2007, Cancer Biology, fourth edition, Oxford University Press, New York

Simstein, R., Burow, M., Parker A., Weldon, C., and Beckman, B. 2003, Apoptosis, Chemoresistance, and Breast Cancer: Insights From the MCF-7 Cell Model System. Exp Biol Med., 228:995-1003

Wang, S., Kotamraju, S., Konorev, E., Kalivendi, S., Joseph, J., and Kalyanaraman, B., 2002, Activation of Nuclear Factor-kB During Doxorubicin-Induced Apoptosis in Endothelial Cells and Myocytes is Pro-apoptotic: The Role of Hydrogen Peroxide, Biochem. J, 367:729-740 